\title{
DEMOCRACIA ON-LINE E OS DESAFIOS DA PROPAGANDA ELEITORAL FALSA NA INTERNET E MÍDIAS SOCIAIS
}

\section{Humberto Luis Versola*}

RESUMO: O artigo tem por objetivo realizar breve estudo acerca dos reflexos da propaganda eleitoral falsa veiculada pela internet e mídias sociais no Estado Democrático de Direito e na ordem constitucional eleitoral. A análise deve partir do enfrentamento do conflito entre o direito fundamental à liberdade de expressão e comunicação e direito fundamental à segurança e estabilidade jurídica nas relações sócio-jurídico-eleitorais, exigindo do Estado a efetivação de políticas administrativas e judiciais na tutela desses bens jurídicos difusos na consolidação da democracia.

PALAVRAS-CHAVE: Processo eleitoral; Propaganda eleitoral; Notícia falsa; Liberdade de expressão; Segurança jurídica-eleitoral.

\section{ONLINE DEMOCRACY AND THE CHALLENGES OF FALSE ELECTORAL PROPAGANDA ON THE INTERNET AND SOCIAL MEDIA}

\begin{abstract}
This article aims at carrying out brief study of the reflexes of fake electoral propaganda aired on the Internet and social medias in the Democratic - rule of-law state and in the Constitutional Electoral Order. The analyzes of the issue starts from the confront between the fundamental right to freedom of expression and communication and the fundamental right to safety and legal stability in electoral legal relations, urging from the State the effectiveness of administrative and judicial policies in the protection of these diffuse assets in the consolidation of democracy.
\end{abstract}

KEY-WORDS: Electoral process, Electoral propaganda, Fake news, Freedom of speech, Electoral legal security

\section{Introdução}

O presente artigo tem como objeto principal analisar as novas tendências da soberania popular na construção do Estado Democrático de Direito contemporâneo, uma vez que a essência do poder político ampara-se na vontade popular. No impulso de alcançar a efetiva soberania do poder político, houve o reconhecimento de direitos fundamentais à liberdade de comunicação e expressão do homem, através da integração do pensamento, ideias, opinião e

\footnotetext{
* Mestre em Direito pela UNESP; Professor de Direito Constitucional, Ciência Política e Direito Tributário nos Cursos de Direito da LIBERTAS - Faculdades Integradas e do UNIFEG - Centro Universitário da Fundação Educacional Guaxupé; Advogado. E-mail: humberto.versola@yahoo.com.br
} 
convicções dos programas político-partidários, proporcionando conhecimento e segurança jurídica no processo eleitoral representativo. Nesse contexto, a propaganda eleitoral é uma ferramenta indispensável na construção do Estado Democrático, uma vez que aproxima os sujeitos da relação jurídico-eleitoral.

Observar-se-á que a propaganda eleitoral constitui-se uma espécie de propaganda política destinada à difusão de ideias com o objetivo de persuadir ou consolidar as decisões do titular da soberania no exercício do poder político, conferindo legitimidade ao processo eleitoral. Assim, merece registrar-se que as propagandas eleitorais deverão desenvolver-se em consonância com um sistema normativo garantidor de segurança jurídica e estabilidade nas relações sócio-políticas, destacando-se a rigorosa observância dos princípios da legalidade, liberdade de expressão e veracidade, sobretudo, na propaganda eleitoral contemporânea realizada pela internet e mídias sociais.

Entretanto, as plataformas digitais, em que pese tornarem-se ferramentas facilitadoras na aproximação das relações jurídico eleitorais, surgem como um grande desafio para a segurança do Estado Democrático de Direito nos últimos anos, uma vez que a veiculação de notícias falsas (Fake News) tornou-se prática recorrente na manipulação da liberdade política e, consequentemente, comprometem o processo eleitoral democrático.

Adota-se, para os fins de desenvolvimento do presente artigo, o método jurídicodedutivo, através da análise qualitativa consolidada pelo levantamento legislativo e bibliográfico, a fim de se obter fundamentos suficientes para a compreensão do alcance e conteúdo do tema em debate.

\section{Democracia e operacionalidade do poder político}

A democracia do século XXI converteu-se em um direito fundamental contemporâneo de quarta geração, uma vez que confere legitimidade a todas as formas de convivência política (BONAVIDES, 2010, p. 521). Tornou-se uma garantia constitucional de observância necessária na consolidação dos valores da cidadania, igualdade, liberdade e justiça social. Direito que se consolidará desde que materializado pela efetiva participação popular no exercício do poder político.

Desse ponto de vista, a democracia sustenta-se pelo exercício da soberania popular como elemento identificador e incontrastável do Estado democrático contemporâneo, uma vez que cada membro da comunidade estatal é titular de cada parcela do poder soberano quando 
exerce ativamente seus direitos políticos na escolha dos governantes, conferindo assim, legitimidade ao exercício do poder estatal e consolidando o vínculo jurídico-político do cidadão com o Estado.

A soberania, "de acordo com o sentido democrático, leva ao entendimento de que a legitimidade dos mandatos eletivos só é possível se relacionada a um ato visível de declaração popular" (MORAES, 2006, p. 127-128). Desse modo, a essência da democracia representativa é o poder que emana do povo através de ato manifesto, como se extrai do art. 14 da Constituição Federal de 1988, a qual dispõe que a "soberania popular será exercida pelo sufrágio universal e pelo voto direto e secreto, com valor igual para todos [...]”. Portanto, a soberania popular está intrinsecamente relacionada aos direitos políticos.

Cumpre destacar que os direitos políticos são direitos fundamentais de primeira geração, relacionados à dignidade humana. "São direitos de liberdade, civis e políticos, os primeiros do catálogo constitucional, correspondendo, no enfoque histórico, à fase inicial do constitucionalismo ocidental" (BONAVIDES, 2010, p. 255). De fato, são os direitos políticos que possibilitam aos indivíduos operacionalizarem o exercício do poder político.

Ao dissertar sobre os direitos políticos (OLIVEIRA, 2018, p. 24) afirma que

\footnotetext{
[...] instrumentos que o cidadão possui para, manifestando a sua vontade, de algum modo, terminar por influenciar nas decisões governamentais, seja de forma indireta, através da escolha de seus representantes no poder, seja de forma direta, nos termos preconizados pela Constituição, como ocorre com o plebiscito, o referendo e a iniciativa popular.
}

A moderna democracia ocidental e os fundamentos de Estado Democrático de Direito têm por bases principais a soberania popular, como fonte de todo o poder legítimo, traduzindose através da vontade geral que a exerce diretamente ou por meio de representantes eleitos. Quanto à primeira, este exercício direto do poder político operacionaliza-se através do plebiscito, referendo e iniciativa popular, indicando a democracia participativa, garantindo-se efetivo poder de decisão em última instância. A democracia semidireta materializa-se como se o povo titular da soberania realmente governasse, presumindo-se que a vontade representativa seja a mesma vontade popular, através da alienação parcial da vontade política. Desta forma, o povo exerce a função de colaborador político e jurídico, uma vez que participa do poder político e legislativo.

\section{Direito fundamental à liberdade de expressão e propaganda eleitoral}


Em sociedades marcadas por situações de injustiça institucionalizada, através de conflitos e desigualdades estruturais, a efetividade dos direitos fundamentais torna-se urgente na construção de democracias autênticas. Houve assim, um reconhecimento de direitos e uma garantia da própria liberdade de comunicação e expressão do homem, através da integração do pensamento, ideias, opinião e convicções dos programas político-partidários àqueles que detêm a soberania no exercício do poder político.

Cumpre anotar a diferenciação entre a propaganda política e a propaganda eleitoral, uma vez que a primeira é um gênero que possui espécies de propaganda que são a institucional, intrapartidária e eleitoral, permitindo-se a divulgação da ideologia política, já a propaganda eleitoral viabiliza a divulgação das propostas dos candidatos aos cargos eletivos. (SILVA FILHO, 2018, p. 30).

Nesse contexto, a propaganda eleitoral é uma ferramenta essencial na concretização do Estado Democrático, sobretudo na consolidação da liberdade como elemento imprescindível na configuração do princípio da dignidade da pessoa humana. Assim, é perceptível a eficácia da propaganda eleitoral na consolidação da segurança jurídica do processo eleitoral, uma vez que constitui-se em instrumento de divulgação de propostas dos partidos, coligações e candidatos a cargos eletivos.

Nesse sentido, o entendimento esposado por (GOMES 2018, p. 531)

Denomina-se propaganda eleitoral a elaborada por partidos políticos e candidatos com a finalidade de captar votos do eleitorado para investidura em cargo público-eletivo. Caracteriza-se por levar ao conhecimento público, ainda que de maneira disfarçada ou dissimulada, candidatura ou os motivos que induzam à conclusão de que o beneficiário é o mais apto para o cargo em disputa.

Vale ressaltar a forma de realização e o sentido da propaganda eleitoral quanto ao sujeito ativo da relação jurídica no processo eleitoral. No que tange à forma de realização, entende-se que a mesma poderá apresentar-se de maneira expressa ou subliminar. Em relação à propaganda eleitoral expressa tem-se que "[...] é aquela que pode ser percebida e compreendida racionalmente na dimensão consciente da mente; por isso, o teor de sua mensagem é claro, induvidoso" (GOMES, 2018, p. 531). Por outro lado, as mensagens subliminares estão diretamente interligadas com o campo subjetivo da compreensão, sendo que os estímulos dirigem-se especificamente à " [...] dimensão do inconsciente da mente e visa atingir certos efeitos, como induzir o destinatário a realizar determinada ação ou adotar determinado ponto de 
vista, instigando-lhe opiniões (positivas ou negativas)" (GOMES, 2018, p. 532), portanto, valese de conteúdo político-eleitoral inseridos em um discurso ou comunicação que podem ser percebidos pelo destinatário.

Quando se define propaganda eleitoral a partir do seu sentido, tem-se que a propaganda eleitoral concebe o positivo ou negativo e, a partir destes critérios poderão ser criadas normas que visam garantir sua instrumentalidade nas eleições. No âmbito positivo, ocorre a exaltação do beneficiário, destacando-se as qualidades e realizações de suas políticas púbicas, transmitindo uma imagem com a qual os eleitores possam facilmente se identificar. Quanto à definição acerca da propaganda eleitoral pelo sentido negativo, compreende-se que esta se apresenta como o oposto lógico da primeira, visto que tem como objetivo a desqualificação dos candidatos oponentes, apresentando fatos total ou parcialmente verdadeiros ou mesmo falsos, sobre a ausência de características morais ou aptidão necessária à investidura em cargo eletivo.

Nessa toada, afirma (GOMES, 2018, p. 533-534)

Esses anúncios publicitários, não surpreendentemente, são destinados a tornar o adversário aparecer incompetente, corrupto, distante [out-of-touch], desagradável, e, geralmente, em favor de todos os tipos de coisas terríveis [dreadful things]. Tais anúncios podem exibir uma foto comprometedora ou mesmo adulterada de um político oponente, ou usar imagens granuladas em preto-e-branco [grainy Black-andwhite footage] para fazer suas ações parecerem ameaçadoras. Tais anúncios podem ser moderados ou fortes.

Contudo, é necessário que se interprete com ponderação acerca do que se tem por sentido negativo da propaganda eleitoral para que não se esbarre em censura velada às críticas que são tecidas com afinco e prudência a respeito de certas ações partidárias, eleitorais e até mesmo institucionais, uma vez são relevantes para o eleitorado e fazem parte do leque de informações legitimamente utilizadas na definição do voto.

Neste sentido (OSÓRIO, 2017, p. 228) delibera que

A crítica política - dura, mordaz, espinhosa, ácida - é peça essencial ao debate democrático, sendo natural em campanhas eleitorais a utilização de estratégias de desqualificação de oponentes, realçando defeitos, pontos fracos, erros e manchas em suas biografias. Além de inevitável, a propaganda negativa pode ser benéfica ao processo democrático.

Desta maneira entende-se que a propaganda eleitoral oferece um duplo benefício, pois os candidatos garantem visibilidade na transmissão de ideias e projetos, bem como na prestação 
de contas do que foi realizado, por outro lado, há também um ganho para democracia ao passo que os possíveis eleitores destes candidatos valer-se-ão desta difusão pública regida por lei para formar suas convicções.

\title{
3. Aspectos principiológicos da propaganda político eleitoral
}

As relações jurídicas constroem-se amparadas em regras e princípios, os quais possibilitam aplicabilidade coerente, hegemônica e eficaz da tutela sobre os bens jurídicos fundamentais do Estado Democrático de Direito. Contudo, é notório que os princípios jurídicos ganharam força normativa a partir da constitucionalização do Direito, sobretudo a partir do fenômeno do neoconstitucionalismo e a ascensão dos princípios como instrumentos de garantia de justiça, equidade e valoração da pessoa humana estampada na figura central do princípio da dignidade humana.

Observa-se que a norma é o gênero do sistema jurídico normativo, onde a regra é a espécie do conteúdo de prescrição do binômio preceito-sanção no âmbito dos limites que o ordenamento permite ou proíbe, por outro lado, surge a espécie do princípio com fundamento de validade no direito positivo de modo expresso ou implícito. Os princípios servem de fundamento para a interpretação e aplicação do Direito, pois instituem razões prima facie, ou seja, à primeira vista de decidir.

Nesta esteira, (ESPÍNDOLA, 2015, p. 6) leciona

\begin{abstract}
...os princípios constituem verdadeiros parâmetros de aferição de constitucionalidade do sistema jurídico; fazem dos princípios normas prenhe de direitos; fazem dos princípios os principais sentidos hermenêuticos da ordem jurídica; sumariam as estruturas básicas de justiça, que estabelecidas na Constituição, pelos princípios constitucionais, ganham vigo e materialidade. Através dos princípios constitucionais se positivam os principais valores éticos, políticos e jurídicos ordenadores da Sociedade e do Estado; dos princípios constitucionais, em termos jurídico-positivos, podemos extrair os grandes sentidos da Democracia Constitucional Contemporânea.
\end{abstract}

Portanto, conclui-se que violar um princípio é muito mais grave que desrespeitar uma norma. A desatenção ao princípio implica ofensa não apenas a um mandamento obrigatório específico, mas todo um sistema normativo, sendo a mais grave forma de ilegalidade ou inconstitucionalidade, dependendo do escalão do princípio violado, representando violação de sua estrutura mestra (MELLO, 2008, p. 53). 
Nesse contexto, as relações jurídico-eleitorais têm sua construção organizada em sistemas que garantam sua operabilidade e aplicabilidade no campo fático de maneira incisiva e dinâmica, devendo proporcionar segurança e estabilidade jurídica nas relações sócio-políticas. Destaque-se que há um regime jurídico-eleitoral autônomo, o qual corresponde a um conjunto sistematizado de princípios e regras próprias que lhe conferem identidade e coerência. Assim, concebe-se que o direito eleitoral regulamenta as relações jurídico-eleitorais, fundamentando-se primariamente nas construções principiológicas que guarnecem sua aplicabilidade no processo eleitoral concreto e consolidando a lisura do exercício do poder político pela população.

No sistema jurídico brasileiro, os princípios do direito eleitoral são implícitos, uma vez que não se encontram descritos na $\mathrm{CF}$ ou nas leis que tratam sobre a disciplina, fundamentando a estrutura normativa do sistema eleitoral brasileiro em busca de harmonização e legitimidade do processo representativo democrático.

Nesse sentido, vale destacar os ensinamentos de (OLIVEIRA, 2018, p. 43)

São princípios eleitoras: princípio da anualidade (anterioridade), princípio da atipicidade eleitoral (in dubio pro candidato), princípio da primazia da eleição direta, princípio da intermediação democrática dos partidos políticos, princípio da temporalidade na investidura eleitoral, princípio da federalização, princípio da delegação, princípio da legalidade da propaganda eleitoral, princípio da liberdade na propaganda eleitoral e princípio do poder de polícia na propaganda eleitoral. (Grifo nosso)

A segurança e estabilidade jurídica no processo eleitoral amparam-se no princípio da juridicidade, sustentando que as relações jurídico-eleitorais devem observar o conjunto de normas que legitimam o processo eleitoral, exigindo que os parâmetros da propaganda eleitoral sejam realizados na forma prevista em lei (Lei no 13.877/2019) além das Resoluções aprovadas pelo Plenário do Tribunal Superior Eleitoral (TSE). Todavia, é praticamente impossível que a lei preveja toda e qualquer espécie de propaganda eleitoral tendo em vista os novos instrumentos publicitários, sendo possível a realização de propaganda eleitoral pela forma não prescrita em lei, desde que não proibida.

No que tange à liberdade de expressão de promover as ideologias partidárias desponta como princípio complementar ao princípio da legalidade, garantindo que os atos políticos partidários sejam pautados na legalidade, contudo sem sofrer limitações, desde que respeitadas as diretrizes normativas, tais como, o tempo (realizar a partir de 16 de agosto do ano das eleições) e lugar (proibição de propaganda em bens públicos). Nesta senda de liberdade da propaganda eleitoral, vislumbra-se a afirmativa de que “[...] o ordenamento jurídico brasileiro 
dispensa licença e autorização do Poder Público para realização de qualquer ato de propaganda eleitoral" (OLIVEIRA, 2018, p. 50). Evidencia-se que mesmo havendo omissão quanto à forma, permitindo a realização da propaganda não prevista e nem proibida em lei, nenhuma propaganda eleitoral é absolutamente livre.

Assim, no sentido de exercer a liberdade imbricada com a legalidade, tem-se o artigo 248 do Código Eleitoral ${ }^{1}$, firmando a convicção de que não se pode impedir a propaganda eleitoral, nem inutilizá-la desde que esta esteja em conformidade a legislação eleitoral vigente, permitindo certa discricionariedade no âmbito da propaganda eleitoral, visto que caso uma espécie de propaganda não seja proibida por lei, ela será permitida.

Destaque-se ainda, o princípio da veracidade ${ }^{2}$, o qual visa proibir a divulgação de fatos inverídicos ou que distorçam situações ou degradem pessoas e instituições influenciando negativamente a opinião do eleitor (SILVA FILHO, 2018, p. 38).

\title{
3.1 Propaganda eleitoral na internet e mídias sociais
}

Em razão das inovações tecnológicas nas comunicações advindas da internet e mídias sociais, a liberdade de expressão e pensamento permitiu que todo cidadão adquirisse voz crítica na construção do poder político, demonstrando a metamorfose social ocasionada pelo acontecimento tecnológico. Neste contexto, os candidatos ao exercício de cargos políticos estão lançando mão desta ferramenta para a integração com a população, sobretudo por seu baixo custo e fácil acesso.

Observa, com propriedade, (SILVA FILHO, 2018, p. 171)

\begin{abstract}
No campo das telecomunicações a internet é uma parte gigante do mundo que hoje habitamos, em razão da abrangência de seu alcance e da celeridade com que as informações tramitam na rede. Merece atenção as inúmeras possibilidades que hoje tem o cidadão eleitor de acessar uma propaganda, sobretudo se for observado o avanço da tecnologia com a disponibilização da internet em computadores, smartphones, relógios inteligentes e tablets. Daí sua importância para o meio político.
\end{abstract}

Diferente da propaganda veiculada nos meios tradicionais de propaganda em massa, através do rádio, televisão e jornais, a internet é uma ferramenta que pode ser utilizada por

\footnotetext{
${ }^{1}$ O art. 248 do Código Eleitoral estipula que: Ninguém poderá impedir a propaganda eleitoral, nem inutilizar, alterar ou perturbar os meios lícitos nela empregados.

${ }^{2}$ Lei $n^{\circ}$ 9.504/1997. “Art. 145 (...) II- usar trucagem, montagem ou outro recurso de áudio ou vídeo que, de qualquer forma, degradem ou ridicularizem candidato, partido ou coligação ou veicular programa com esse efeito".
} 
políticos, partidos e coligações para o pedido direto e expresso de votos. Acerca do tema (GOMES, 2018, p. 344) discorre "A democracia contemporânea passa por uma fase sem paralelos históricos, e o principal fator de tamanha novidade é, sem dúvida alguma, a Internet”. Todavia, a realização de propaganda eleitoral no ambiente virtual necessita de ampla regulamentação, visto tratar-se de veículo aberto a todos os eleitores para recorrerem ao maior acesso à informação.

Assim, o Marco Regulatório da Internet (lei 12.965/2014) pode ser visto como uma lei brasileira que regulamenta as diretrizes que deverão ser observadas tanto por pessoas físicas quanto jurídicas, sendo uma ferramenta de estabilidade organizacional atuante no âmbito da internet, estabelecendo parâmetros a serem observados na construção de uma difusão informativa segura, sempre com transparência em relação aos dados cambiados e promovendo facilidade na inclusão desta tecnologia a todos os espaços brasileiros.

Sobre o tema (OLIVEIRA, 2014, p. 5) defende que

O Marco Civil não é (e nem quis ser) uma ilha normativa deserta, isolada das demais fontes jurídicas. Ele é um dos vários pontos de irradiação normativa que disciplina o comportamento dos indivíduos no mundo virtual. [...] A Constituição Federal, como lei fundamental do nosso País, dá as coordenadas principiológicas incontestes do ordenamento jurídico, ao fluxo da qual tramitarão as interpretações que transbordarão do Marco Civil da Internet.

Contudo, não basta apenas uma organização legislativa acerca do conteúdo em si, devendo haver aplicabilidade e efetividade, principalmente no campo de proteção de direitos e garantias individuais, pois não se deve permitir que a evolução tecnológica levante suspeita e dúvidas acerca do enfraquecimento da democracia, especialmente na invasão de privacidade, abusando da proliferação de falsas notícias. Nestes termos, a esfera de comunicação traz para o direito eleitoral questões acerca dos limites de exposição de informações “[...] tanto quanto ao direito de ser informado em conformidade com os princípios constitucionais, quanto à liberdade intercomunicativa de ambos os polos: candidato - eleitor” (GOMES, 2018, p. 477).

A reforma eleitoral e a regulamentação disponibilizada através da justiça eleitoral permitem que candidatos, partidos políticos e coligações não se deparem com dificuldades e limitações anteriormente encontradas, viabilizando o livre acesso à informação, através da vinculação de vídeos, propostas e propagandas com acesso $24 \mathrm{~h}$ por dia, tornando efetivo o exercício da democracia nas relações jurídico-eleitorais (CERQUEIRA; CERQUEIRA, 2015, p. 492).

Não obstante, ao mesmo tempo em que a propaganda eleitoral encontra terreno fértil na internet também enfrenta vários problemas, ganhando relevo, o poder de polícia, 
principalmente referente à normatização e à imposição de limitações, atuando na contenção de atividade ilícitas na órbita das relações eleitorais e garantindo estabilidade, segurança e transparência ao respectivo processo eleitoral.

A problemática do presente artigo concentra-se no enfrentamento da resolução de conflitos entre direitos fundamentais na seara da propaganda eleitoral, ou seja, de um lado, o direito fundamental à liberdade de expressão e pensamento veiculada pela inimaginável velocidade da transmissão das informações dos novos mecanismos digitais e a possibilidade de divergência de suas interpretações, de outro lado, a segurança do eleitor na formação da opinião no exercício do poder político e manutenção do Estado Democrático.

Dito isto, é certo que o conteúdo e o mecanismo digital utilizado para repassar estas informações podem influenciar decisivamente no resultado das eleições, pois é notório que nas eleições para Presidente da República do ano de 2018 a propaganda digital e a ausência de regulamentação específica e fiscalização própria resultaram o atual cenário político-eleitoral brasileiro, que padeceu com as denominadas notícias falsas (fake news) ${ }^{3}$.

Por este motivo, deve-se ter uma rigorosa e funcional legislação e fiscalização acerca destes aspectos formais que dão corpo a este fenômeno, pois a internet é indubitavelmente o campo fértil para que esta prática possa se desenvolver e fragilizar o processo eleitoral democrático.

\section{Propaganda eleitoral digital e notícia falsa}

Desta forma, considera-se a internet e as mídias sociais como veículos criadores de um novo contexto para as relações político eleitorais, aproximando e conferindo transparência nas relações-jurídico eleitorais, as quais por muitos anos encontravam-se distantes e obscuras.

Destarte, é possível afirmar que a internet está inserida na conjuntura cotidiana social, permitindo que candidatos e partidos estabeleçam uma relação recíproca com seu eleitorado.

\footnotetext{
${ }^{3}$ Uma das páginas utilizadas para ataques virtuais e para estimular o ódio contra supostos adversários do presidente Jair Bolsonaro foi criada a partir de um computador localizado na Câmara dos Deputados.... Conforme tal depoimento, os participantes do grupo "Gabinete do Ódio" não apenas articulavam sistematicamente a divulgação de Fake News no período eleitoral de 2018, mas também elaboraram um "cronograma de ataques" para "assassinato de reputações", o que configura a prática de cyberbullying até a presente data", afirmou o deputado.... Outra publicação na página mostra a jornalista da Folha Patrícia Campos Mello, com a legenda de que a repórter "tentou destruir a campanha" de Bolsonaro, o que não é verdade. As informações foram enviadas pelo Facebook à CPMI das Fake News no Congresso, a partir de um pedido de quebra de sigilo referente a contas no Instagram feito pela Comissão Parlamentar Mista de Inquérito .... A página, chamada Bolsofeios, também foi registrada a partir de um telefone utilizado pelo secretário parlamentar do deputado Eduardo Bolsonaro (PSL-SP), Eduardo Guimarães.... https://legis.senado.leg.br/comissoes/comissao?1\&codcol=2292. Acesso em 04/03/2020.
} 
Isto porque a rede mundial de computadores permite que grandes distâncias sejam reduzidas em questões de segundos, poupando a locomoção para lugares remotos com o intuito de capturar votos e promover suas ideias. Assim, surge para os sujeitos da relação jurídica eleitoral a possibilidade de se comunicar, interagir, descobrir e até facilitar a decisão levada a sufrágio.

No entanto, estas novas ferramentas facilitadoras para a captação de votos devem respeitar o texto inscrito na Resolução $23.551 / 2017$ e na Lei $n^{\circ} 9.504 / 1997$, para que não haja dúvidas quanto a sua boa-fé no processo eleitoral, evitando ao máximo a ocorrência de ilicitudes nesse cenário.

Assim, inicia-se um paralelo entre a teoria e a prática eleitoral ao demonstrar a dificuldade em separar a hipótese de propaganda subliminar atemporal da classificada por irregular. Desta forma, no tocante às normas supracitadas cabe a diferenciação entre o simples marketing pessoal livre e a propaganda com intenção eleitoral explicita realizada antes do período permitido (legalmente). Nesses termos, apesar da diferenciação, ambas as práticas criam um vínculo no inconsciente do eleitor, o que por muitas vezes dificulta a sua caracterização concreta ante os tribunais eleitorais. A irregularidade da propaganda eleitoral surge como "[...] restrição ao princípio da liberdade, posto que, os sujeitos de direito que optam pela prática ilícita, automaticamente, perdem o seu direito de liberdade. Já que a liberdade só é legitima quando não fere ou invade os limites impostos" (VELLOSO e AGRA 2016, p.112).

Nesses termos o Tribunal Regional Eleitoral do Paraná fixou o entendimento

\begin{abstract}
A propaganda eleitoral ilícita há que ser aquela em que o pré candidato atua como se candidato fosse, visando influir diretamente na vontade dos eleitores, mediante ações que traduzem um propósito de fixar sua imagem e suas linhas de ação política, em situação apta, em tese, a provocar um desequilíbrio no procedimento eleitoral relativamente a outros candidatos, que somente após as convenções poderão adotar esse tipo de propaganda. Recurso Eleitoral n. 2.157- classe 2 - pato branco Paraná, relator Dr. Eduardo Fagundes. Acórdão n 20.570. Proferido em 15 de julho de 1996. Publicado em 29-07-1996.
\end{abstract}

A propaganda eleitoral na internet permite a livre manifestação do pensamento, sendo somente passível de limitação quando ocorrer ofensa à honra de terceiros ou divulgação de fatos inverídicos, vedando-se o anonimato durante a campanha eleitoral por meio da rede mundial de computadores - internet e outras mídias sociais, tais como: Twitter, Instagram, Facebook, Snapchat e WhatsApp. Todavia, um grande desafio surgiu para a Justiça Eleitoral nos últimos anos, que é o enfrentamento às notícias falsas (Fake News) por ocasião do processo eleitoral, o que se deve a diversos fatores, mas principalmente ao fato de que se"[...] toda e 
qualquer notícia falsa deve ser combatida, não menos verdade é que os instrumentos utilizados para esse combate não devem limitar em excesso a propaganda eleitoral, muito menos a liberdade de expressão" (SODRÉ, 2018, p. 367). Surge assim, “[...] um grande dilema, pois de um lado está o combate às notícias falsas e, de outro, a liberdade de expressão". Atualmente, tratando-se de processo eleitoral, requer especial atenção, principalmente pela gama de condutas que possibilitam não só a criação de notícias falsas, mas também sua reprodução e divulgação a toda sociedade, maculando a legitimidade do processo eleitoral democrático.

Diante deste contexto (GOMES, 2018, p. 355) afirma

A internet está criando novos e atormentados malefícios para a privacidade, uma vez que deu às pessoas uma possibilidade sem precedentes de disponibilizar e disseminar ao redor do mundo informação uma sobre as outras. Para enfrentar estes problemas, necessitamos repensar a privacidade para a era da Informação. Se falharmos, iremos nos deparar com severas limitações ao autodesenvolvimento agora e no futuro.

No contexto das notícias falsas no âmbito da propaganda eleitoral merece destaque o dark post, sendo a informação direcionada a um público específico e o deepfake que em tradução literal significa falsificação profunda, o qual consiste em apertada síntese, na utilização de tecnologia de ponta para manipular imagens e sons, que "reproduzem falsamente a imagem e o som, em alta qualidade, não sendo possível identificar se a pessoa e o som na notícia divulgada são verdadeiros ou não" (SODRÉ, 2018, p. 380). Exatamente por isso a influência das Fake News no processo eleitoral, dada dificuldade de se afastar uma notícia verdadeira de uma inverídica. Trata-se de estratégias reprováveis que faltam com a verdade e claramente desequilibram o pleito democrático.

Sobre dark post leciona ( SODRÉ, 2018, p. 379)

Por este instrumento, no cenário político eleitoral, existindo a polarização entre dois candidatos, lança-me mão de um inusitado recurso. Uma mesma informação é repassada de forma individual a dezenas, centenas ou milhares de eleitores, porém com "sinais" trocados. Por exemplo, havendo um candidato que defende a legalização do aborto, divulga-se o seu real posicionamento perante os eleitores que são manifestamente contra o aborto; já em relação aos eleitores que são favoráveis ou toleram o aborto, através de manipulação de frases ou palavras desconexas, tenta-se passar a impressão de que o candidato é contra o aborto. Ou seja, o dark post, como subproduto das fake news, em um processo eleitoral, tem o potencial de fazer com que o candidato, no caso, perca voto dos dois lados do eleitorado.

Observe-se ainda, a problemática dos robôs ou bots, programas gerados para replicar automaticamente milhares de mensagens, likes, twitters a respeito de um mesmo tema, fazendo 
com que aquele assunto alcance o topo das redes sociais. Trata-se, portanto, de um impulsionamento eletrônico que faz com que uma notícia irrelevante rapidamente se torne conhecida de todos nas redes sociais e, a partir desse ponto, passa a ser replicada também por seres humanos, sugerindo que de fato as pessoas acham o tema relevante e o que inicialmente foi replicado por robôs ganha grande proporção no pleito eleitoral.

Ressalte-se as recentes notícias falsas nas eleições norte-americanas, francesa, alemã, Reino Unido e Brasil. Exatamente por isso, é imperiosa a atuação do Estado quando caracterizado o fenômeno das notícias falsas, o que enfrenta diversos problemas, a exemplo da familiarização do profissional do Direito com os termos e mecanismos técnicos afetos à informática. De fato, aqui ganha relevo a inter-relação entre diversas áreas que compõe o saber.

Logo, o Tribunal Superior Eleitoral mantém um trabalho preventivo, instituindo o Conselho Consultivo para pautar suas ações, Conselho este formado por servidores do próprio Tribunal, integrantes do Exército, do Ministério da Defesa, da Agência Brasileira de Inteligência, do Comitê Gestor da Internet, do Ministério da Ciência, Tecnologia, Inovações e Comunicações, da SaferNet Brasil e da Fundação Getúlio Vargas. Criado pela Portaria n ${ }^{\circ}$ 949, de 07 de dezembro de 2017, tem por objetivo o desenvolvimento de pesquisas e estudos sobre as regras eleitorais e a influência da internet nas eleições, em especial quanto "[...] às Fake News e o uso de robôs na disseminação de informações; opinar sobre matérias que lhe sejam submetidas pelo Presidente do Tribunal Superior Eleitoral”; e, ainda, “[...] propor ações e metas voltadas ao aperfeiçoamento das normas jurídicas" (SODRÉ, 2018, p. 385).

Outro instrumento normativo que foi instituído com finalidade de assegurar eficiência e segurança no que diz respeito às Fake News é a Resolução no 23.551, de 2017, que regulamentou o pleito eleitoral em 2018 no âmbito federal e estadual, com o objetivo de tornar igualitário e protegido os direitos e garantias fundamentais eleitorais, tanto de quem pleiteia um cargo eletivo bem como de quem irá votar. A resolução em voga delibera e organiza, bem como traz penalidades administrativas, cíveis e criminais para quem violá-la.

No que tange o combate às Fake News propriamente dito, a Resolução 23.551/2017 foi utilizada no julgamento da Representação $n^{\circ}$ 0600546-70, julgada pelo Ministro substituto Sérgio Banhos em 2018, o qual deferiu em decisão monocrática a liminar que determinou ao Facebook a remoção de publicações, no prazo de até quarenta e oito horas, referentes à précandidata à Presidência da República, Marina Silva, cuja imagem estava sendo compartilhada sendo associada à corrupção e à Lava-Jato, bem como ao Partido dos Trabalhadores. A Representação movida pela Rede Sustentabilidade visava justamente o combate às Fake News, 
o que restara comprovado na Reclamação em voga. Ainda, como determinação do Ministro, restou ordenado que o Facebook, no prazo de até 10 dias, fornecesse todos os dados sobre a origens das postagens, das páginas hospedadas em seu domínio e o responsável pelas publicações.

Destaque-se também, a criação da Comissão Mista Parlamentar de Inquérito em 04/09/2019, com o objetivo de investigar os ataques cibernéticos e o uso de perfis falsos para influenciar os resultados das eleições de 2018. Embora instituída por tempo determinado, a referida Comissão demonstra a preocupação da Polícia Federal no enfrentamento das Fake News no processo eleitoral. Porém, outros segmentos precisam ser alcançados, a exemplo dos juízes eleitorais que trabalham nos pleitos, de modo a tornar a eleição um processo igualitário e que a propaganda eleitoral não seja um instrumento de difusão de informações falsas.

Em relação às eleições de 2018 no Brasil, em todas suas deliberações, o que se notou foi justamente uma maior incidência de campanhas e candidatos que utilizaram a internet, seus perfis sociais e também a interatividade instantânea, visto que houve a possibilidade de "lives", ou seja, de candidatos se comunicarem em conversas com os eleitores em geral, podendo responder perguntas que eram elaboradas durante o debate, o que certamente foi positivo às eleições, visto a rapidez e alcance desta forma de comunicação.

Diante de todo o exposto não há como negar a importância da atuação estatal para sustar qualquer difusão de informações inverídicas, por meio das Fake News, em virtude de seu poder devastador no contexto democrático e político.

\section{Poder de polícia e tutela jurisdicional coletiva na propaganda eleitoral falsa}

O Estado Democrático, a Ordem Constitucional e o processo eleitoral idôneo constituem direitos difusos de interesse público primário em razão da dimensão do dano social e em razão dos valores atrelados aos bens jurídicos tutelados, exigindo do Estado políticas administrativas e judiciais que tutelem as dimensões política e social da democracia.

Neste contexto, o poder de polícia no âmbito das relações jurídico-eleitorais ocorre com dúplice função, ou seja, atua de modo positivo e negativo na medida em que apresenta-se como instrumento garantidor da não ocorrência de atos ilícitos, bem como delibera que atos lícitos sejam praticados no processo eleitoral, atuando de maneira regulamentadora e impositiva. Portanto, assume função garantidora da soberania estatal e do Estado Democrático de Direito, gerando segurança jurídica e credibilidade às instituições. 
Ao juiz eleitoral é conferido o poder de polícia ${ }^{4}$ para que possa fiscalizar o cumprimento das regras e coibir abusos, fazendo cessar o ilícito da propaganda e determinando sanções cabíveis, conferindo tratamento equânime entre os sujeitos do processo eleitoral (SILVA FILHO, 2018, p. 81). Desta forma, “[...] o juiz eleitoral deve determinar a suspensão dos atos e propaganda que sejam ilegais de ofício. Aliás, tal competência será do juiz eleitoral, ainda que a propaganda seja para eleições presidenciais, federais ou estaduais" e "[...] no que diz respeito às normas que disponham acerca da inelegibilidade devem respeitar o princípio da anualidade" (OLIVEIRA, 2018, p. 50).

No âmbito jurisprudencial, o Tribunal Superior Eleitoral (TSE) decidiu por meio do julgamento do Min. Carlos Ayres Britto no Recurso Especial Eleitoral n ${ }^{\circ}$ 26.251/MG que o "ato de propaganda eleitoral aquele que leva ao conhecimento geral, ainda que de forma dissimulada, a candidatura, mesmo que apenas postulada, a ação política que se pretende desenvolver ou razões que induzam a concluir que o beneficiário é o mais apto ao exercício de função pública (...)".

Ressalte-se que o poder de polícia manifesto pelo agir de ofício em relação aos atos de ilegalidade no sistema eleitoral brasileiro encontra limitações, quando "esse poder de polícia não pode aplicar multa estabelecida em lei. Isto pode ser feito apenas através da representação citada no art. 96 da lei 9.504/87". Assim “[...] esta representação poderá ser ajuizada por partido político, candidato, coligação ou pelo Ministério Público Eleitoral e a competência para julga-los será dos juízes auxiliares do TSE ou TRE” (OLIVEIRA, 2018, p. 50).

A existência de um espaço virtual alheio ao real distorce as verdadeiras dimensões decorrentes da incorporação das tecnologias da informação e comunicação ao quotidiano. Assim, “[...] a internet não é mais vista como um mundo à parte, mas sim, como uma parte do mundo. Atentos a essa realidade, os provedores desenvolvem, constantemente, novas ferramentas" todas "[...] com o intuito de atrair usuários e mantê-los sempre conectados, capazes de captar novos adeptos" (VELLOSO e AGRA, 2016, p. 120). Portanto, os espaços ocupados pela internet e mídias sociais configuram limites de difícil compreensão e

\footnotetext{
${ }^{4}$ TSE. Resolução 23.551/2017.

${ }^{5}$ BRASIL. Tribunal Superior Eleitoral. Jurisprudência do Tribunal Superior Eleitoral v. 18, n.2, p.303, abr./jun. 2007. Recurso Especial Eleitoral no 26.251/MG. Rel. Min. Carlos Ayres Britto. Brasília, 15.03.2007. Disponível em: http://www.tse.jus.br/hotsites/catalogo-publicacoes/pdf/revista_jurispridencia/RJTSE18_2.pdf >. Acesso em; 18/10/2019.

${ }^{6} \mathrm{O}$ artigo 96 possui a seguinte redação: Salvo disposições específicas em contrário desta lei, as reclamações ou representações relativas ao seu descumprimento podem ser feitas por qualquer partido político, coligação ou candidato, e devem dirigir-se: I - aos juízes eleitorais, nas eleições municipais; II - aos tribunais regionais eleitorais, nas eleições federais, estaduais e distritais; III - ao Tribunal Superior Eleitoral, na eleição presidencial.
} 
determinação, porém, são espaços facilmente acessíveis à população com poder decisório no pleito eleitoral. Por isso, a importância de identificarem-se os gestores da internet no âmbito eleitoral para que seja possível extrair e aplicar informações em conformidade com o ordenamento jurídico.

Assim, a atuação estatal é indispensável na imposição de limites e possibilidades do espaço virtual, através da regulamentação da utilização das tecnologias no processo eleitoral ${ }^{7}$ desse novo viés democrático, aperfeiçoando a forma de legislar de acordo com a vontade e a necessidade social, uma vez que o uso de tecnologias digitais contribui para estimular diálogos e debates públicos acerca de suas propostas políticas garantidoras da legitimidade do processo democrático eleitoral.

Ressalte-se que o princípio da demanda ${ }^{8}$ não vigora na tutela de polícia no processo eleitoral eivado de propaganda falsa, podendo o juiz, atuar de ofício em caso de veiculação de propaganda em desacordo com a legislação eleitoral, sendo-lhe possível emitir tutela inibitória para cessar a veiculação de propaganda irregular, restrito apenas, na instauração de procedimento que culmine em aplicação de multa ${ }^{9}$ (SILVA FILHO, 2018, p. 82).

As Resoluções do Tribunal Superior Eleitoral e Leis esparsas firmam as regras eleitorais, regulamentando os procedimentos, estabelecendo o funcionamento legal da matéria, sempre em conformidade com a vontade e o poder popular, para máxima democracia e transparência no exercício da atividade governamental. O poder normativo da Justiça Eleitoral reserva ao TSE a competência para a edição de Resoluções com o objetivo de regulamentar o processo eleitoral. Assim, com a Resolução 23.551, de 18 de dezembro de 2017, tem-se a regra geral, objetiva, das práticas lícitas que regulam a propaganda eleitoral no país, determinando-se condutas normativas referentes às regras, prazos, vedações, multas, atos lícitos e ilícitos nas propagandas intrapartidárias, antecipadas e regulares eleitorais.

\footnotetext{
7 Art. 57-B: A propaganda eleitoral na internet poderá ser realizada nas seguintes formas: I - em sítio do candidato, com endereço eletrônico comunicado à Justiça Eleitoral e hospedado, direta ou indiretamente, em provedor de serviço de internet estabelecido no País; II - em sítio do partido ou da coligação, com endereço eletrônico comunicado à Justiça Eleitoral e hospedado, direta ou indiretamente, em provedor de serviço de internet estabelecido no País; III - por meio de mensagem eletrônica para endereços cadastrados gratuitamente pelo candidato, partido ou coligação; IV - por meio de blogs, redes sociais, sítios de mensagens instantâneas e assemelhados, cujo conteúdo seja gerado ou editado por candidatos, partidos ou coligações ou de iniciativa de qualquer pessoa natural.

${ }^{8}$ Art. $2^{\circ}$ CPC "O processo judicial começa por iniciativa da parte e se desenvolve por impulso oficial, salvo as exceções previstas em lei”.

${ }^{9}$ TSE Súmula 18. Conquanto investido de poder de polícia, não tem legitimidade o juiz eleitoral para, de ofício, instaurar procedimento com a finalidade de impor multa pela veiculação de propaganda eleitoral em desacordo com a Lei $\mathrm{n}^{\circ} 9.504097$.
} 
O enfrentamento da notícia falsa como elemento que incide diretamente na formação da vontade política e a consequente tutela judicial da ordem constitucional e do processo eleitoral democrático deverá ocorrer no âmbito da tutela jurisdicional coletiva, em que pese a existência de tutela coletiva no âmbito eleitoral, através da ação de impugnação de mandato eletivo. A presente proposta deverá ser veiculada mediante Emenda Constitucional, permitindose ao Ministério Público a propositura de ação de investigação judicial eleitoral por divulgação de notícia falsa com reflexos de natureza cível indenizatória ao causador dos danos sóciopolíticos à sociedade, além da suspensão dos direitos políticos e destinação dos recursos para o Fundo Especial de Financiamento de Campanha (FEFC).

No dizer de (DIDIER JR.; ZANETI JR. 2018, p. 38)

\begin{abstract}
Os processos coletivos servem à "litigação de interesse público" (LIP); ou seja, serve às demandas judiciais que envolvam, para além dos interesses meramente individuais, aqueles referentes à preservação da harmonia e à realização dos objetivos constitucionais da sociedade e da comunidade constitucionalmente reconhecida, a exemplo dos consumidores, do meio ambiente, do patrimônio artístico, histórico e cultural, saúde, educação (...).
\end{abstract}

Ao lado de todos os avanços que marcam o desenvolvimento do processo coletivo na tutela dos direitos difusos, impõe-se a regulamentação da matéria como mecanismo de se inibir a divulgação da notícia falsa no processo eleitoral.

\title{
Considerações finais
}

O presente artigo discute novas tendências da soberania popular na construção do Estado Democrático de Direito contemporâneo no contexto das relações jurídico-eleitorais, uma vez que o pleno exercício dos direitos políticos assegura o direito fundamental à liberdade. Desta maneira, faz-se necessário o estreitamento do diálogo entre os sujeitos do processo eleitoral na divulgação e efetivo conhecimento das propostas dos partidos e candidatos a serem implementadas na consolidação da democracia.

Nesse contexto, a propaganda eleitoral tornou-se essencial na concretização do Estado Democrático, sobretudo na consolidação da segurança jurídica do processo eleitoral. Todavia, as relações jurídico-eleitorais deverão operacionalizar-se de forma proporcionar segurança e estabilidade jurídica, amparadas no princípio da veracidade, dentre outros, conferindo-lhes identidade e coerência. 
Por outro lado, em razão das inovações tecnológicas nas comunicações advindas da internet e mídias sociais, permitiu-se a ampliação da integração com o eleitorado, sobretudo por seu baixo custo e fácil acesso. Ocorre que as plataformas digitais tornaram-se ferramentas facilitadoras na criação e divulgação de notícias falsas no âmbito das relações eleitorais, maculando a legitimidade do processo eleitoral democrático, uma vez que a velocidade das consequências junto aos eleitores desequilibra a lisura do processo eleitoral democrático.

Assim, desponta o conflito entre os direitos fundamentais à liberdade de expressão e comunicação e o direito fundamental à segurança jurídica no processo eleitoral com consequências irreparáveis ao Estado Democrático, à segurança da Ordem Constitucional e ao processo eleitoral, exigindo do Estado a implementação de políticas administrativas e judiciais na tutela dos interesses difusos na consolidação da democracia. Em resposta a esta questão, o Estado deverá enfrentá-la através da implantação da tutela jurisdicional coletiva, a qual permitirá ao Ministério Público e ao Judiciário, no exercício do sistema de freios e contrapesos, impor medidas de natureza administrativa, penal e cível aos responsáveis pela divulgação de notícias falsas nas relações jurídicas eleitorais destinando os recursos de natureza indenizatória para o Fundo Especial de Financiamento de Campanha (FEFC).

Evidentemente, há muitos obstáculos de cunho político e administrativo a serem enfrentados e superados na efetiva implantação de uma tutela objetiva do direito fundamental à segurança do processo eleitoral frente às notícias falsas. Todavia, acredita-se que as questões propostas inicialmente foram respondidas, constituindo além de pontos de chegada, também pontos de partida para o enfrentamento dos desafios na construção do processo eleitoral seguro face às irreversíveis inovações tecnológicas.

Em remate, as respostas apresentadas às questões levantadas neste artigo, longe de tornarem-se definitivas, devem constituir-se em indicativos para estimular os gestores públicos e os operadores do direito a apresentarem outras propostas na construção de um sistema jurídico eleitoral capaz e torná-lo aplicável na tutela do Estado Democrático e, assim, obter a plenitude da dignidade da pessoa humana.

\section{Referências bibliográficas}

BANDEIRA DE MELLO, Celso Antônio. Curso de Direito Administrativo. 25 ed. São Paulo: Malheiros, 2008.

BONAVIDES, Paulo. Ciência Política. 17 ed. São Paulo: Malheiros, 2010. 
CERQUEIRA, Thales Tácito; CERQUEIRA, Camila Albuquerque. Direito Eleitoral esquematizado. São Paulo: Saraiva, 2011.

COSTA, Adriano Soares da. Instituições de Direito Eleitoral. 7. ed. Rio de Janeiro: Lúmen Júris, 2008.

DIDIER JÚNIOR, Fredie; ZANETI JÚNIOR, Hermes. Curso de direito processual civil: processo coletivo. 12. ed. Salvador: JusPodvm, 2018.

ESPÍNDOLA, Ruy Samuel. Democracia, Constituição e princípios Constitucionais: notas de reflexão no âmbito do direito constitucional brasileiro. Revista da faculdade de Direito da Universidade Federal do Paraná. p. 1-13, Paraná, 2015.

GOMES, José Jairo. Direito eleitoral. 13. ed. São Paulo: Atlas, 2018.

MORAES, Alexandre de. Constituição do Brasil interpretada e Legislação Constitucional. São Paulo: Atlas, 2006.

OLIVEIRA, Carlos Eduardo Elias de. Aspectos Principais da Lei no 12.965, de 2014, o Marco Civil da Internet: subsídios à comunidade jurídica. Brasília: Núcleo de Estudos e Pesquisas/CONLEG/ Senado, abr./2014 (Texto para Discussão n ${ }^{\circ}$ 148). <Disponível em: www.senado.leg.br/estudos>. Acesso em 12/maio/2019.

OLIVEIRA, João Paulo Oliveira. Direito eleitoral. Salvador: JusPodivm, 2018.

OSÓRIO, Aline. Direito eleitoral e liberdade de expressão. Belo Horizonte: Fórum, 2017.

SILVA FILHO, Lídio Modesto da. Propaganda eleitoral: de acordo com a minirreforma eleitoral e com as Resoluções 23.551/2017 e 23.554/2017, 2018.

SODRÉ, Paulo César Alves. As Fakes News e a Propaganda Eleitoral: da liberdade de expressão à legitimidade do processo eleitoral. São Paulo: Juruá, 2018.

VELOSO, Carlos Mário da Silva; AGRA, Walter de Moura. Elementos de Direito Eleitoral. São Paulo: Saraiva, 2009. 